\title{
VIVIPARUS MAMILLATUS (KÜSTER, 1852), AND PARTIAL CONGRUENCE BETWEEN THE MORPHOLOGY-, ALLOZYME- AND DNA-BASED PHYLOGENY IN EUROPEAN VIVIPARIDAE (CAENOGASTROPODA: ARCHITAENIOGLOSSA)
}

\author{
ALEKSANDRA RYSIEWSKA ${ }^{1}$, SEBASTIAN HOFMAN² ${ }^{2}$ ARTUR OSIKOWSKI ${ }^{3}$, LUBOŠ BERAN ${ }^{4}$, \\ VLADIMIR PEŠIĆ ${ }^{5}$, ANDRZEJ FALNIOWSKI ${ }^{1 *}$
}

\begin{abstract}
${ }^{1}$ Department of Malacology, Institute of Zoology and Biomedical Research, Jagiellonian University, Gronostajowa 9, 30-387 Cracow, Poland (e-mail: andrzej.falniowski@uj.edu.pl);

AR (1) https://orcid.org/0000-0002-9395-9696, AF 니 https://orcid.org/0000-0002-3899-6857

${ }^{2}$ Department of Comparative Anatomy, Institute of Zoology and Biomedical Research,

Jagiellonian University, Gronostajowa 9, 30-387 Cracow, Poland; (ㅇ https://orcid.org/0000-0001-6044-3055

${ }^{3}$ Department of Animal Anatomy, Institute of Veterinary Science, University of Agriculture in Krakow, Cracow, Poland; (1) https://orcid.org/0000-0001-6646-2687

${ }^{4}$ Nature Conservation Agency of the Czech Republic, Regional Office Kokořínsko - Máchův kraj Protected Landscape Area Administration, Mělník, Czech Republic; (i) https://orcid.org/0000-0002-5851-6048

${ }^{5}$ Department of Biology, Faculty of Sciences, University of Montenegro, Cetinjski put b.b.,

81000 Podgorica, Montenegro; (i) https://orcid.org/0000-0002-9724-345X

*corresponding author
\end{abstract}

ABSTRACT: Shells and three DNA loci of Viviparus mamillatus (Küster, 1852), V. contectus (Millet, 1813), $V$. acerosus Bourguignat 1862 and V. viviparus (Linnaeus, 1758) were analysed. Despite slight morphological differences between the nominal species, and the near-absence of differences in nuclear 18SrRNA (18S) and histone 3 (H3) loci, mitochondrial cytochrome oxidase subunit I (COI) confirmed species distinctness of all but $V$. mamillatus. The latter should be synonymised with $V$. contectus. The comparison of COI-based phylogeny with the earlier, allozyme- and morphology-based, phylogenies suggests that $V$. contectus and $V$. viviparus are the most distantly related, in the DNA tree $V$. acerosus is closer to $V$. contectus, while in the allozyme and morphology-based tree - to V. viviparus.

KEY WORDS: species distinctness, shell, shell sculpture, radula, soft parts, mtDNA, COI

\section{INTRODUCTION}

Viviparidae are big, dioecious, ovoviviparous freshwater gastropods, whose history - and invasion of the freshwater habitats - dates back to the Palaeozoic, more precisely to the Devonian (FRETTER \& GRAHAM 1962, HASZPRUNAR 1988). In Europe the genus Viviparus Montfort, 1810 is represented by widely distributed and rather ubiquitous $V$. contectus (Millet, 1813), somewhat less widely distributed $V$. viviparus (Linnaeus, 1758) and $V$. ace- rosus Bourguignat, 1862. V. ater (De Cristofori et Jan, 1832) is known only from northern Italy and a few localities in Switzerland. V. janinensis (Mousson, 1859) has been recorded only from Lake Pamvotis in western Greece, but its geographical distribution (spanning ca. $130 \mathrm{~km}$ ) as well as its shell morphology suggest its identity with $V$. hellenicus (Clessin, 1879) from Lake Trichonida in SW continental Greece (FALNIOWSKI et al. 1996a, 1998); the latter 
species often synonymised with $V$. ater (e.g. WELTERSCHULTES 2012). It has to be noted that all the species distinction in the European Viviparidae is based on the shell alone.

KÜSTER (1852: pl. 2, figs 1-5) described Paludina mamillata: "a species showing transitional features between $[V$. contectus] and [V. viviparus]" from "Montenegro, in a creek that flows into Lake Scutari, frequent". Later it was recorded from Croatia to North Albania (Lake Shkodra: DHORA 2002, GLÖER \& PEŠIĆ 2007). Its shell is usually olive brown, prominently striated, sometimes with malleate pattern, apex blunt, 5-6 convex whorls; juvenile shells with three colour bands (KÜsTER 1852). In May 2018, we collected a few specimens of $V$. mamillatus in Montenegro. The aim of this paper was to test its distinctness and phylogenetic relationships within Viviparus applying DNA markers. Some time ago the phylogeny of the other European viviparid species was reconstructed on the basis of morphological and allozymic characters (FALNIOWSKI et al. 1993a, 1996a, b, c, 1997, 1998). Thus there was an opportunity to compare morphology-, allozyme- and DNAbased phylogenies.

\section{MATERIAL AND METHODS}

The snails were collected from six localities (Table 1, Fig. 1), and fixed in $80 \%$ analytically pure ethanol. The shells were photographed with a CANON EOS 50D digital camera attached to NIKON SMZ-18 stereoscopic microscope with the dark field. The shells of young $V$. mamillatus were cleaned in ultrasonic cleaner and examined using a HITACHI S-4700 scanning electron microscope, applying the techniques described by FALNIOWSKI (1990).
DNA was extracted from foot tissue. The tissue was hydrated in TE buffer $(3 \times 10 \mathrm{~min}$.); then total genomic DNA was extracted with the SHERLOCK extracting kit (A\&A Biotechnology) and the final product was dissolved in $20 \mu \mathrm{l}$ TE buffer. The extracted DNA was stored at $-80^{\circ} \mathrm{C}$ at the Department of Malacology, Institute of Zoology and Biomedical Research, Jagiellonian University in Kraków. Details of PCR conditions, primers used and sequencing were

Table 1. Sampling localities with geographical coordinates (bold) and references used in the present study

\begin{tabular}{|c|c|c|c|c|}
\hline Id & Site & Coordinates & COI GB numbers & References \\
\hline \multicolumn{5}{|c|}{ Viviparus acerosus (Bourguignat, 1862) } \\
\hline 1 & $\begin{array}{l}\text { Czech Republic, Švihov dam water } \\
\text { reservoir }\end{array}$ & $49^{\circ} 37^{\prime} 25^{\prime \prime} \mathrm{N} \quad 15^{\circ} 14^{\prime} 52^{\prime \prime} \mathrm{E}$ & $\begin{array}{l}\text { MK517425- } \\
\text { MK517427 }\end{array}$ & present study \\
\hline \multicolumn{5}{|c|}{ Viviparus ater (De Cristofori \& Jan, 1832) } \\
\hline & Switzerland, Lake Zurich, Goldbach & - & FJ405882 & SENGUPTA et al. 2009 \\
\hline \multicolumn{5}{|c|}{ Viviparus chui Yen, 1937} \\
\hline & - & - & NC_035733 & WANG et al. 2017 \\
\hline \multicolumn{5}{|c|}{ Viviparus contectus (Millet, 1813) } \\
\hline 2 & $\begin{array}{l}\text { Czech Republic, Libický luh NNR, } \\
\text { canal in floodplain forest }\end{array}$ & $50^{\circ} 06^{\prime} 06^{\prime \prime} \mathrm{N} \quad 15^{\circ} 11^{\prime} 07^{\prime \prime} \mathrm{E}$ & $\begin{array}{l}\text { MK517420- } \\
\text { MK517422 }\end{array}$ & present study \\
\hline & Denmark, Haellebaek Lakes & - & EU274557 & JøRGENSEN et al. 2008 \\
\hline & Denmark, Haellebaek Lakes & - & FJ405835 & SENGUPTA et al. 2009 \\
\hline \multicolumn{5}{|c|}{ Viviparus georgianus (I. Lea, 1834) } \\
\hline & USA & - & KY781182 & DAVID et al. 2017 \\
\hline & - & - & AF120634 & GIRIBET \& WHEELER 2002 \\
\hline \multicolumn{5}{|c|}{ Viviparus mamillatus (Küster, 1852) } \\
\hline 3 & Montenegro, M4, Mareza & $42^{\circ} 28^{\prime} 26^{\prime \prime N} \quad 19^{\circ} 10^{\prime} 47^{\prime \prime} \mathrm{E}$ & MK517423 & present study \\
\hline 4 & Montenegro, M8, Crno Oko & $42^{\circ} 29^{\prime} 05^{\prime \prime} \mathrm{N} \quad 19^{\circ} 09^{\prime} 16^{\prime \prime} \mathrm{E}$ & - & present study \\
\hline \multirow[t]{2}{*}{5} & Montenegro, M19, Vranjina & $42^{\circ} 16^{\prime} 54^{\prime \prime} \mathrm{N} \quad 19^{\circ} 08^{\prime} 19^{\prime \prime} \mathrm{E}$ & MK517424 & present study \\
\hline & Macedonia, Lake Ohrid & - & KY574011 & VAN BOCXLAER et al. 2018 \\
\hline \multicolumn{5}{|c|}{ Viviparus viviparus (Linnaeus, 1758) } \\
\hline 6 & $\begin{array}{l}\text { Czech Republic, Velký Osek, } \\
\text { Labe River }\end{array}$ & $50^{\circ} 06^{\prime} 09^{\prime \prime} \mathrm{N} \quad 15^{\circ} 09^{\prime} 28^{\prime \prime} \mathrm{E}$ & $\begin{array}{l}\text { MK517417- } \\
\text { MK517419 }\end{array}$ & present study \\
\hline & Germany, Odra River & - & KY574013 & VAN BOCXLAER et al. 2018 \\
\hline \multicolumn{5}{|c|}{ Viviparus sp. } \\
\hline & Greece, Lake Pamvotis & $-\quad-$ & KY574012 & VAN BOCXLAER et al. 2018 \\
\hline \multicolumn{5}{|c|}{ Bellamya angularis (Müller, 1774) } \\
\hline & - & - & KF535563 & DING et al. 2013 \\
\hline
\end{tabular}


given in SZAROWSKA et al. (2016). Sequences were initially aligned in the MUSCLE (EDGAR 2004) programme in MEGA 6 (TAMURA et al. 2013) and then checked in Bioedit 7.1.3.0 (HALL 1999). The saturation test (XIA 2000, XIA et al. 2003) was performed using DAMBE (XIA 2013). In the phylogenetic analysis additional sequences from GenBank were used (Table 1). The data were analysed using approaches based on Bayesian inference and maximum likelihood (ML). We applied the GTR model, whose parameters were estimated by the RAxML (STAMATAKIS 2014).

The Bayesian analyses were run using MrBayes v. 3.2.3 (RONQUIST et al. 2012) with the default priors. Two simultaneous analyses were performed, each of which lasted 10,000,000 generations, with one cold chain and three heated chains, starting from random trees and sampling the trees every 1,000 generations. The first $25 \%$ of the trees were discarded as burnin. The analyses were summarised as a $50 \%$ majority-rule tree. The ML approach was applied with RAxML v. 8.0.24 (STAMATAKIS 2014). One thousand searches were initiated with starting trees obtained through the randomised stepwise addition maximum parsimony method. The tree with the highest likelihood score was considered as the best representation of the phylogeny. Bootstrap support was calculated with 1,000 replicates and summarised on the best ML tree. RAxML analyses were performed using the free computational resource CIPRES Science Gateway (MiLLER et al. 2010).

\section{RESULTS}

The shells of $V$. contectus (Figs 2-4), V. mamillatus (Figs 5-8), V. acerosus (Figs 9-11) and V. viviparus (Figs 12-14) show interspecies differences described in the literature (e.g. FALNIOWSKI 1989). The shells of the sequenced $V$. mamillatus (Figs 5-8) resemble the ones of $V$. contectus (Figs 2-4). All the sequenced $V$. mamillatus were juvenile, thus their shells do not resemble those typical of this species. This concerns also the specimens from Vranina (locality M19, Figs 5-6), at Lake Skadar, thus representing the topotypes. We have not found any adult specimens in 2018. The adult ones were collected earlier, but fixed not well enough to get COI sequences. Their shells (Figs 15-18) resembled the ones drawn by KÜSTER (1852), reproduced in Figs 19-21. It should be noted that our juvenile sequenced specimens resembled the very young V. mamillatus drawn by KÜSTER (1852: fig. 4). The protoconchs of $V$. mamillatus (Figs 22-23), as well as the sculpture of its first teleoconch whorls (Figs 24-29), with prominent bristles, were similar to the ones found in $V$. contectus (FALNIOWSKI et al. 1996b).

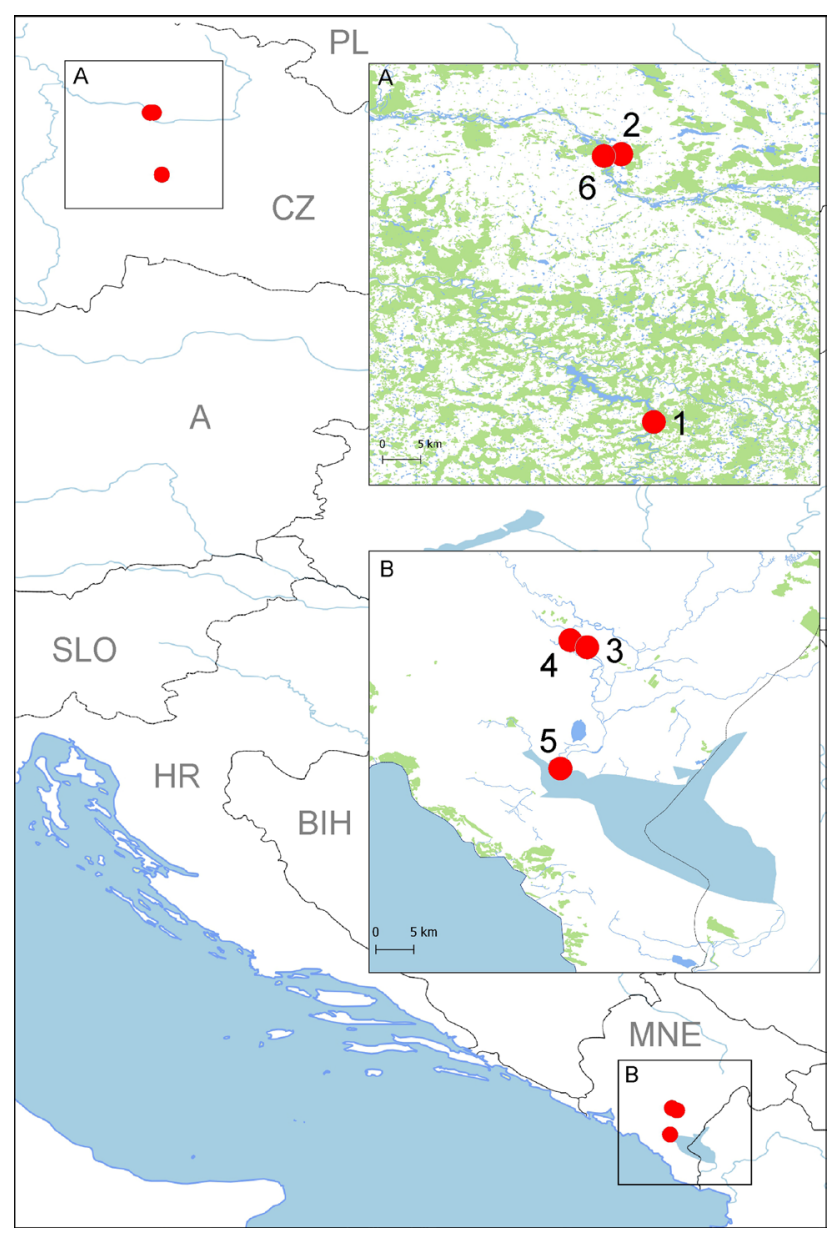

Fig. 1. Localities of the studied Viviparidae (numbers as in Table 1)

In total we analysed three molecular markers: $\mathrm{cy}-$ tochrome oxidase subunit I (COI), histone $3(\mathrm{H} 3)$ and 18SrRNA (18S). The sequences of nuclear 18SrRNA (345 bp, GenBank Accession numbers MK506907MK506920) and histone H3 (283 bp, GenBank Accession numbers MK517428-MK517441) genes were nearly identical in all the studied species. For COI locus (552 bp, GenBank Accession numbers see Table 1) the tests of XIA et al. (2003) revealed no saturation. The topology of the trees obtained from BI and ML analyses was identical.

The cytochrome oxidase subunit I (COI) tree (Fig. 30) confirmed distinctness of all the studied species, defined by their shell character states, with an exception of $V$. mamillatus. The p-distances between the species of Viviparus are given in Table 2. The sequences of our specimens from Montenegro were nearly identical with Viviparus cf. contectus from Lake Ohrid found in GenBank, and very close to the ones of our $V$. contectus, as well as $V$. contectus from Denmark taken from GenBank. The p-distance between $V$. mamillatus and $V$. contectus was 0.026 

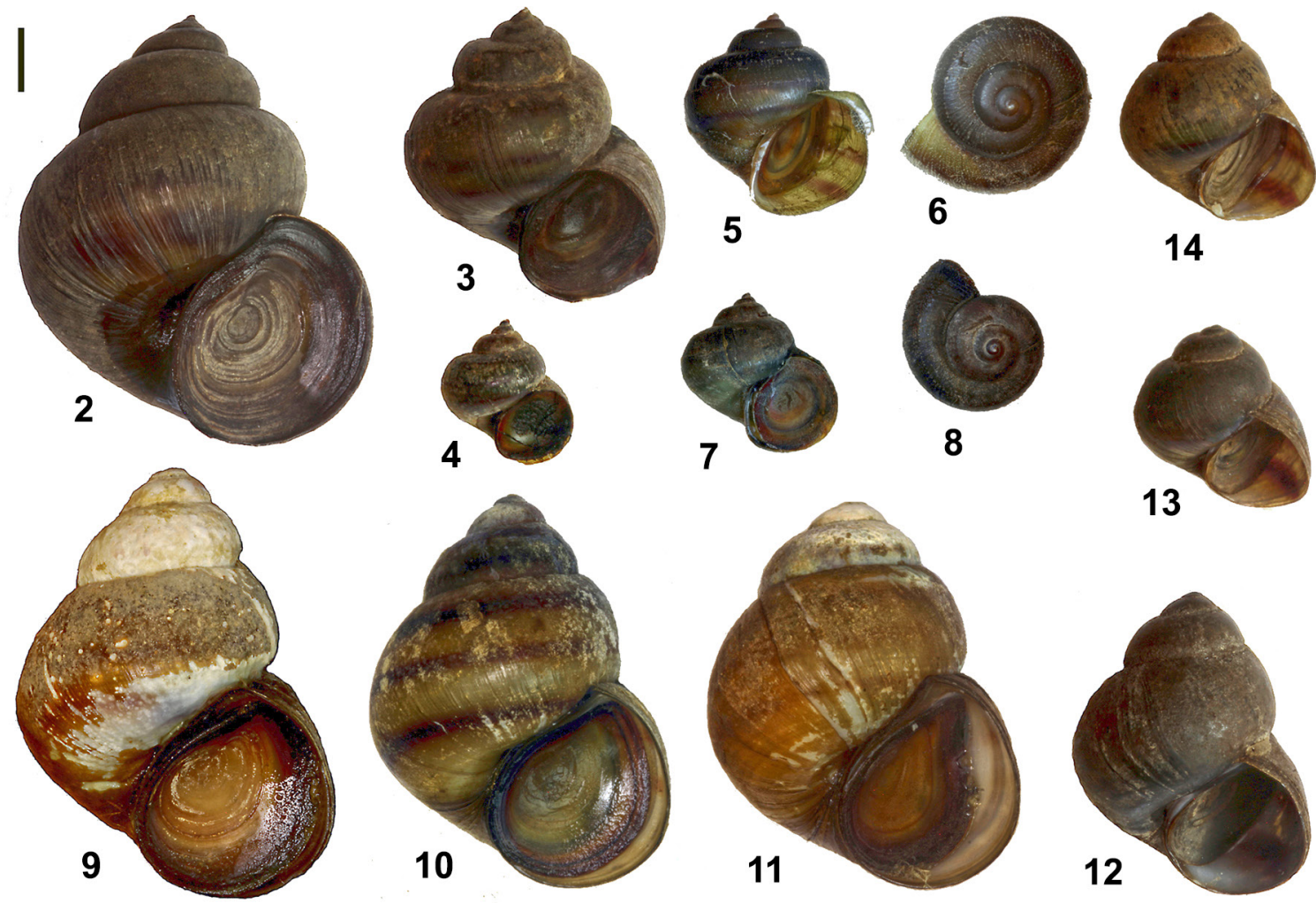

14
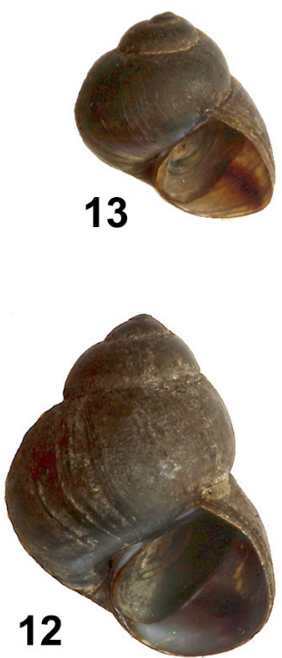

Figs 2-14. Shells of sequenced Viviparus: $2-4-V$. contectus; 5-8 - V. mamillatus: 5-6 - M19, 7-8 - M4; 9-11 - V. acerosus; 12-14 - V. viviparus; scale bar $5 \mathrm{~mm}$
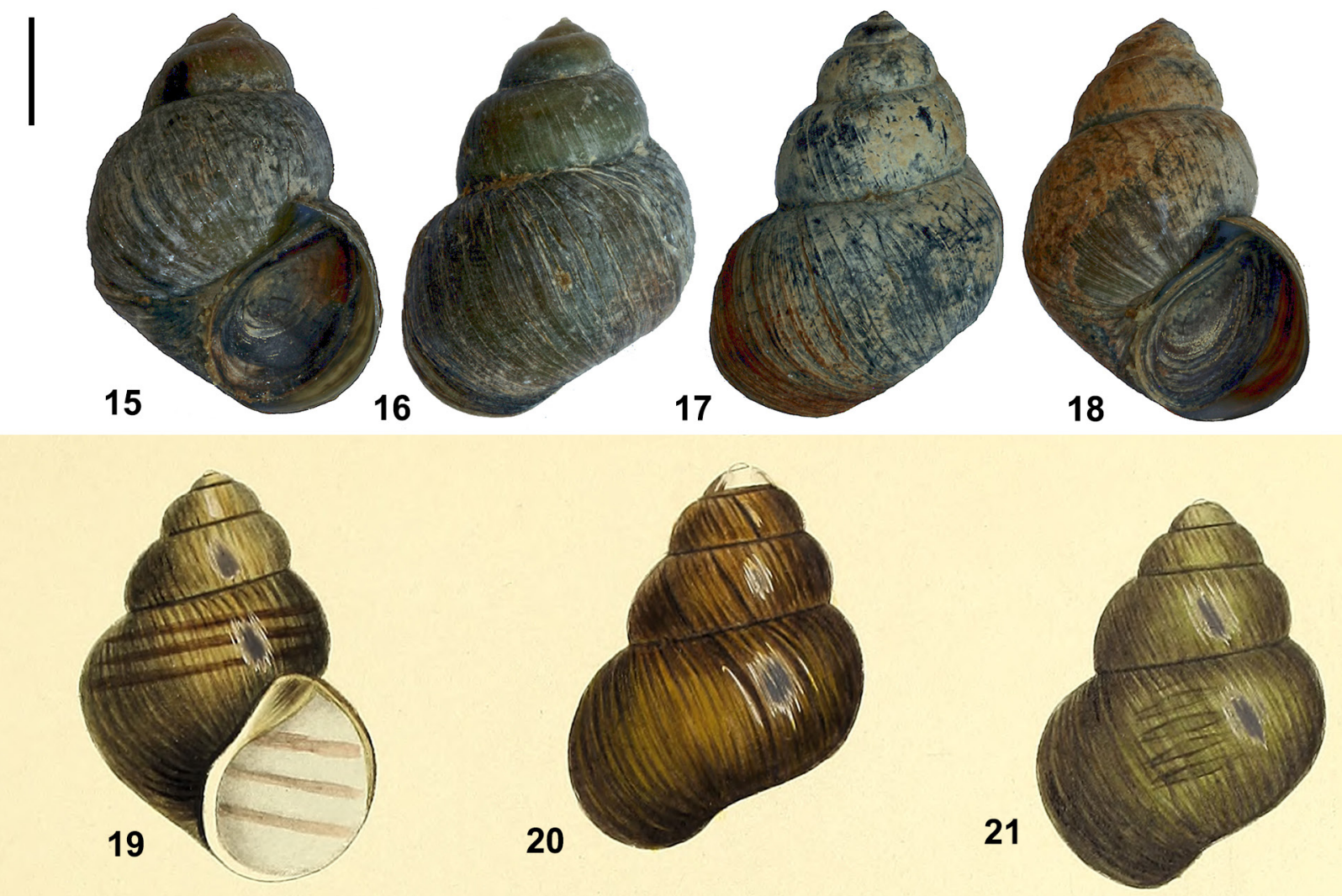

Figs 15-21. Shells of $V$. mamillatus: 15-18 - unsequenced adult specimens from Lake Skadar; 19-21 - original drawings of KÜSTER (1852: pl. 2, figs 1-3); scale bar $10 \mathrm{~mm}$ 

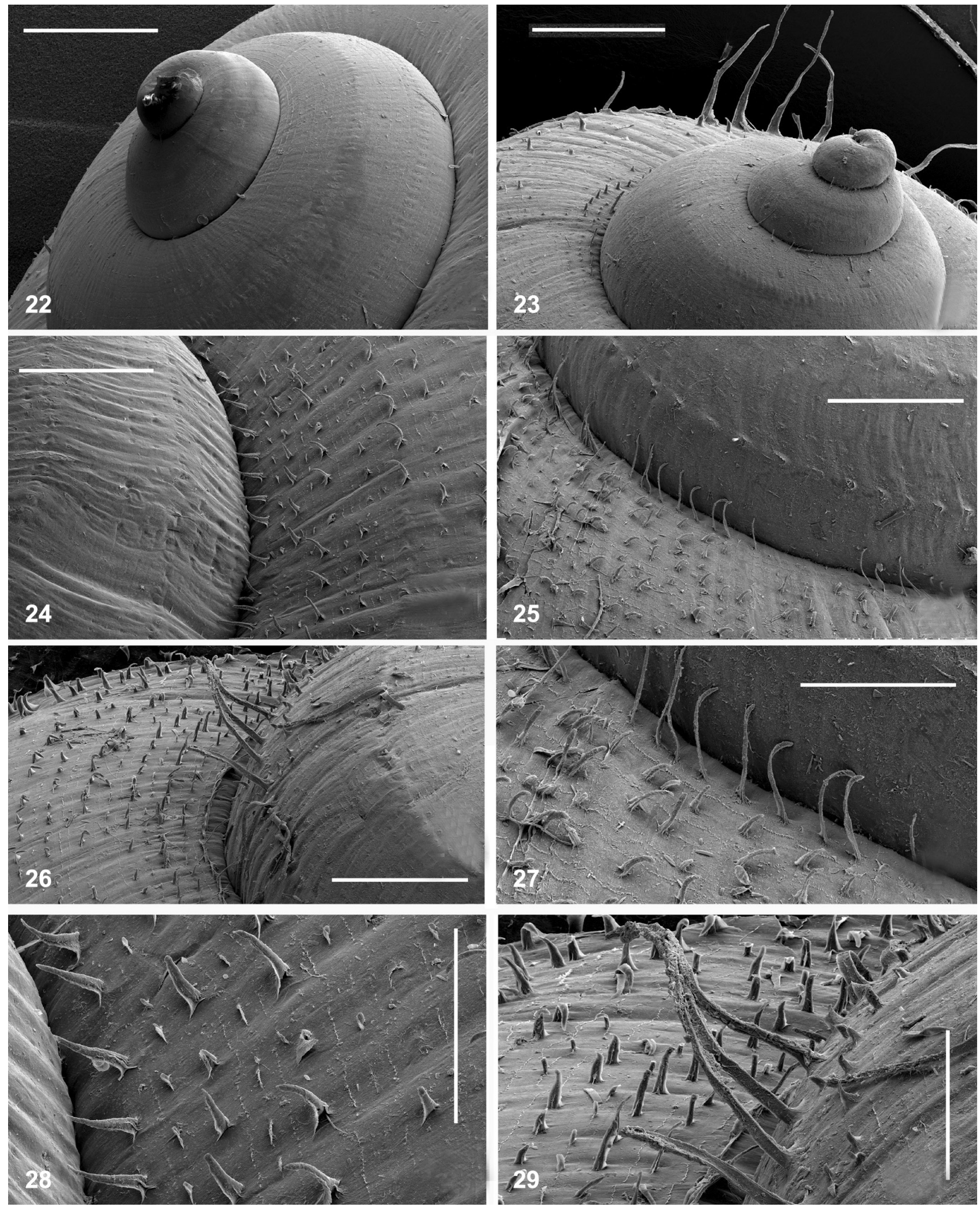

Figs 22-29. SEM photograph of shells of $V$. mamillatus: 22-23 - protoconch, bar equals $1 \mathrm{~mm}$; 24-29 - details of teleoconch sculpture; scale bar $1 \mathrm{~mm}$ in $24-26$, and $0.5 \mathrm{~mm}$ in $27-29$ 


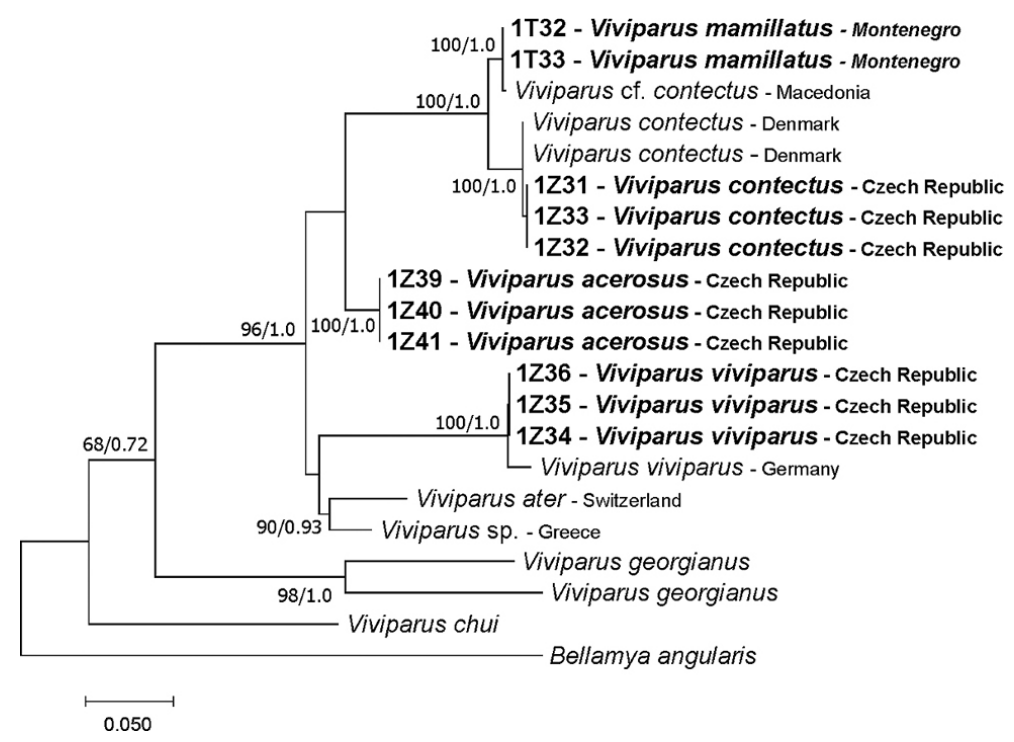

Fig. 30. Cytochrome oxidase subunit I (COI) maximum likelihood tree; bootstrap supports and Bayesian probabilities given

(Table 2). "Viviparus sp." from Lake Pamvotis - most probably representing $V$. janinensis - clustered with $V$. ater, with the p-distance of 0.056 .

The morphology-based trees (Figs 31-32) resemble the one based on allozymes (Fig. 33). The comparison of our COI-based phylogeny (Fig. 30) with the allozyme-based one (Fig. 33) confirms the most distant relationships between $V$. contectus and $V$. viviparus, although in the DNA tree $V$. acerosus is closer to $V$. contectus, while in the allozyme tree - to V. viviparus.

Table 2. The p-distances for COI locus, between the main Viviparus species

\begin{tabular}{llcccccc}
\hline & 1 & 2 & 3 & 4 & 5 & 6 \\
\hline $1 \quad$ V. mamillatus & & & & & & \\
2 & V. contectus & 0.026 & & & & & \\
3 & V. acerosus & 0.078 & 0.084 & & & & \\
4 & V. viviparus & 0.117 & 0.115 & 0.115 & & & \\
5 & V. ater & 0.108 & 0.107 & 0.075 & 0.098 & & \\
6 & V. sp. Greece & 0.103 & 0.097 & 0.060 & 0.091 & 0.056 & \\
\hline
\end{tabular}

Figs 31-33. Inferred non-DNA phylogenies in Viviparus: 31 - based on morphology, non-conchological characters (after FALNIOWSKI et al. 1996a), 32 - maximum parsimony tree considering all the morphological characters listed in FALNIOWSKI et al. (1996b, c, 1997), 33 based on allozymes (after FALNIOWSKI et al. 1996a)

\section{DISCUSSION}

Considering the lack of evident morphological differences between $V$. mamillatus and $V$. contectus, combined with the slight differences in COI, $V$. mamillatus should be regarded as conspecific with $V$. contectus, and thus V. mamillatus (Küster, 1852) becomes a jun-

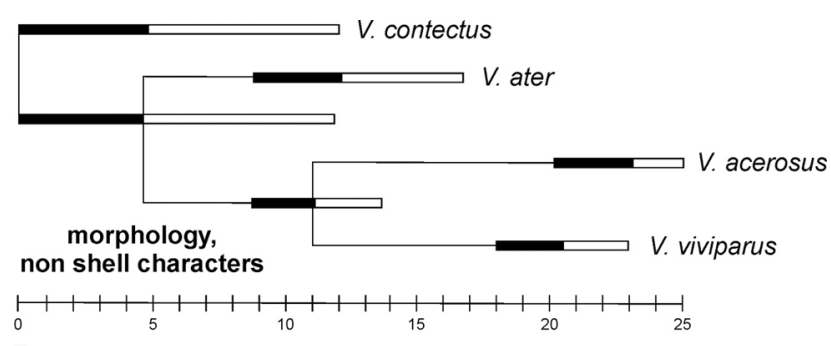

31

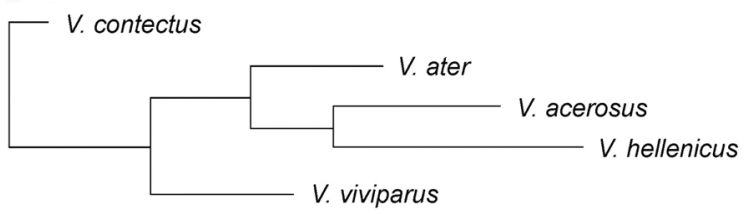

32

all morphology characters

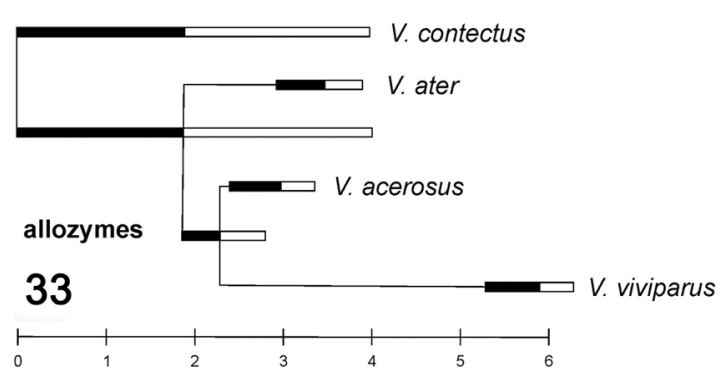

ior synonym of $V$. contectus (Millet, 1813). The range of the latter species should be thus expanded to include Montenegro, Albania and Macedonia (lakes Scutari and Ohrid). Our results certainly do not confirm the suggestion of WELTER-SCHULTES (2012) 
that $V$. mamillatus may be conspecific with $V$. janinensis from Lake Pamvotis. On the other hand, accepting the probable hypothesis that $V$. janinensis is conspecific with $V$. hellenicus, its close relationship with $V$. ater confirms the suggestion of SCHÜTT (1962) and WELTER-SCHULTES (2012) that $V$. hellenicus is a subspecies of $V$. ater. Considering the priority rule, its name should then be $V$. ater janinensis. It should be noted, however, that neither FALNIOWSKI et al. (1997), nor GLÖER \& GEORGIEV (2014) confirm such relationships, based on the shell, radula, and soft parts morphology.

Although morphology need not reflect speciation (FALNIOWSKI 1987, 1992, LARSON 1989, GIUSTI \& MANGANELLI 1992), it reflects it in the case of our Viviparus. The incongruence of morphological and molecular evolution is not rare (CHEVERUD 1988, FALNIOWSKI et al. 1993b, DAVIS 1994, OMLAND 1994). HAASE (1994) found two species of Graziana, morphologically and anatomically different enough

\section{REFERENCES}

Cheverud J. M. 1988. A comparison of genetic and phenotypic correlations. Evolution 42: 958-968. https://doi. org/10.1111/j.1558-5646.1988.tb02514.x

DAVid A. A., ZHOU H., LeWIS A., YhanN A., Verra S. 2017. DNA barcoding of the banded mystery snail, Viviparus georgianus in the Adirondacks with quantification of parasitic infection in the species. American Malacological Bulletin 35: 175-180. https://doi. org/10.4003/006.035.0211

DAVIS G. M. 1994. Molecular genetics and taxonomic discrimination. Nautilus 2 (suppl.): 3-23.

DHORA D. 2002. Studime mbi molusqet e Shqipërisë. Camaj-Pipa, Shkodër.

Ding B. Q., GU Q. H., Husemann M., XiOnG B. X. 2013. Contrasting patterns of diversification across Asia and Africa in the genus Bellamya (Mollusca: Gastropoda: Viviparidae) (unpublished). Available online from GenBank at https://www.ncbi.nlm.nih.gov/nuccore/ KF535563 (accessed 12 December 2018)

EDGAR R. C. 2004. MUSCLE: multiple sequence alignment with high accuracy and high throughput. Nucleic Acids Research 32: 1792-1797. https://doi.org/10.1093/nar/ gkh340

FALNIOWSKI A. 1987. Hydrobioidea of Poland (Prosobranchia: Gastropoda). Folia Malacologica 1: 1-122. https://doi.org/10.12657/folmal.001.001

FALNIOWSKI A. 1989. Przodoskrzelne (Prosobranchia) Polski. I. Neritidae, Viviparidae, Valvatidae, Bithyniidae, Rissoidae, Aciculidae. Zeszyty Naukowe Uniwersytetu Jagiellońskiego, Prace Zoologiczne 35: 1-148.

FALNIOWSKI A. 1990. Anatomical characters and SEM structure of radula and shell in the species-level taxonomy of freshwater prosobranchs (Mollusca: Gastropoda: Prosobranchia): a comparative usefulness study. Folia to justify their specific distinctness, to be genetically identical at all 27 loci. Our study (unpublished) on the Polish Bythinella: B. austriaca (Frauenfeld, 1857) and B. zyvionteki Falniowski, 1987, found no differences in four DNA loci, despite clear interspecific differences in morphology, especially penis.

In the case of our Viviparidae the molecules and morphology are congruent in species distinction. The DNA-based phylogeny also confirms the distant relationship between $V$. contectus and $V$. viviparus, despite the fact that the two species sometimes hybridize (FALNIOWSKI et al. 1993a). On the other hand, considering all the data, the phylogenetic relationships of $V$. ater and $V$. acerosus remain unclear.

\section{ACKNOWLEDGEMENTS}

The study was supported by a grant from the National Science Centre 2017/25/B/NZ8/01372 to ANDRZEJ FALNIOWSKI.
Malacologica 4: 53-142. https://doi.org/10.12657/folmal.004.005

FALNIOWSKI A. 1992. Genus Bythinella Moquin-Tandon, 1855, in Poland (Gastropoda, Prosobranchia, Hydrobiidae. In: GitTENBERGER E., Goud J. (eds). Proceedings of 9th International Malacological Congress, Edinburgh, 31 August-4 September, 1986. Unitas Malacologica, Leiden: 135-138.

FALNIOWSKI A., FIAŁKOWSKI W., SZAROWSKA M., MAZAN K. 1998. Shell biometry characters in species discrimination and classification within the genus Viviparus (Gastropoda: Architaenioglossa: Viviparidae). Malakologische Abhandlungen Staatliches Museum für Tierkunde Dresden 19: 29-45.

FALNIOWSKI A., KOZIK A., SZAROWSKA M. 1993a. Two common European viviparid species hybridize. American Malacological Bulletin 10: 161-164.

FALNIOWSKI A., KOZIK A., SZAROWSKA M., FIAŁKOWSKI W., MAZAN K. 1996a. Allozyme and morphology evolution in European Viviparidae (Mollusca: Gastropoda: Architaenioglossa). Journal of Zoological Systematics and Evolutionary Research 34: 49-62. https://doi. org/10.1111/j.1439-0469.1996.tb00810.x

FALNIOWSKI A., KOZIK A., SZAROWSKA M., RĄPAŁA-KOZIK M., TURYNA I. 1993b. Morphological and allozymic polymorphism and differences among local populations in Bradybaena fruticum (O. F. Müller, 1777) (Gastropoda: Stylommatophora: Helicoidea). Malacologia 35: $371-$ 388.

FALNIOWSKI A., MAZAN K., SZAROWSKA M., KOZIK A. 1997. Tracing the viviparid evolution: soft part morphology and opercular characters (Gastropoda: Architaenioglossa: Viviparidae). Malakologische Abhandlungen Staatliches Museum für Tierkunde Dresden 18: 193-211. 
FALNIOWSKI A., SZAROWSKA M., MAZAN K. 1996b. Embryonic shells of Viviparus - what they may tell us about taxonomy and phylogeny? (Gastropoda: Architaenioglossa: Viviparidae). Malakologische Abhandlungen Staatliches Museum für Tierkunde Dresden 18: 35-42.

FALNIOWSKI A., SZAROWSKA M., MAZAN K. 1996c. Tracing the viviparid evolution: radular characters (Gastropoda: Architaenioglossa: Viviparidae). Malakologische Abhandlungen Staatliches Museum für Tierkunde Dresden 18: 43-52.

FretTer V., Graham A. 1962. British prosobranch molluscs. Their functional anatomy and ecology. Ray Society, London.

GiRIBET G., WheELER W. C. 2002. On bivalve phylogeny: a high-level analysis of the Bivalvia (Mollusca) based on combined morphology and DNA sequence data. Invertebrate Biology 121: 271-324. https://doi. org/10.1111/j.1744-7410.2002.tb00132.x

GIUSTI F., MANGANELLI G. 1992. The problem of the species in malacology after clear evidence of the limits of morphological systematics. In: GITTENBERGER E., GOUD J. (eds). Proceedings of 9th International Malacological Congress, Edinburgh, 31 August-4 September, 1986. Unitas Malacologica, Leiden: 153-172.

GLÖER P., GEORGIEV D. 2014. Redescription of Viviparus sphaeridius Bourguignat 1880 with an identification key of the European Viviparus species (Gastropoda: Viviparidae). Ecologica Montenegrina 1: 96-102.

GLÖER P., PEŠIĆ V. 2007. The freshwater gastropods of the Skadar Lake with the description of Valvata montenegrina n. sp. (Mollusca, Gastropoda, Valvatidae). In: PAVIČEVIČ D., PERREAU M. (eds). Advances in the studies of the fauna of the Balkan Peninsula. Papers dedicated to the memory of Guido Nonveiller. Institute for Nature Conservation of Serbia, Monograph, Belgrade, No. 22: 325-332.

HAASE M. 1994. Differentiation of selected species of Belgrandiella and the redefined genus Graziana (Gastropoda: Hydrobiidae). Zoological Journal of the Linnean Society 111: 219-246. https://doi. org/10.1111/j.1096-3642.1994.tb01484.x

HALl T. A. 1999. BioEdit: a user-friendly biological sequence alignment editor and analysis program for Windows 95/98/NT. Nucleic Acids Symposium Series 41: 95-98.

HASZPRUNAR G. 1988. On the origin and evolution of major gastropod groups, with special reference to the Streptoneura. Journal of Molluscan Studies 54: 367441. https://doi.org/10.1093/mollus/54.4.367

JøRGENSEN A., KRISTENSEN T. K., MAdSEN H. 2008. A molecular phylogeny of apple snails (Gastropoda, Caenogastropoda, Ampullariidae) with an emphasis on African species. Zoologica Scripta 37: 245-252. https:// doi.org/10.1111/j.1463-6409.2007.00322.x

KÜSTER H. C. 1852. Die Gattungen Paludina, Hydrocaena und Valvata. In: Abbildungen nach der Natur mit Beschreibungen. Systematisches Conchylien-Cabinet von Martini und Chemnitz 1 (21), Bauer und Raspe, Nürnberg.
LARSON A. 1989. The relationship between speciation and morphological evolution. In: OTTE D., ENDLER J. A. (eds). Speciation and its consequences. Sinauer Associates Inc., Sunderland, Massachusetts, pp. 579598.

Miller M. A., Pfeiffer W., SchWARTZ T. 2010. Creating the CIPRES Science Gateway for inference of large phylogenetic trees. Proceedings of the Gateway Computing Environments Workshop (GCE), 14 November 2010, New Orleans, LA: 1-8. https://doi.org/10.1109/ GCE.2010.5676129

OMLAND K. E. 1994. Character congruence between a molecular and a morphological phylogeny for dabbling ducks (Anas). Systematic Biology 43: 369-386. https:// doi.org/10.1093/sysbio/43.3.369

RONQUist F., TESLENKO M., VAN DER MARK P., AYRES D., DARLiNG A., HOHNA S., LARGET B., LIU L., SUCHARD M. A., HuELSENBECK J. P. 2012. MrBayes 3.2: efficient Bayesian phylogenetic inference and model choice across a large model space. Systematic Biology 61: 539_ 542. https://doi.org/10.1093/sysbio/sys029

SCHÜTT H. 1962. Neue Süsswasser-Prosobranchier Griechenlands. Archiv für Molluskenkunde 91: 157166.

SENGUPTA M. E., KRISTENSEN T. K., MADSEN H., JøRGENSEN A. 2009. Molecular phylogenetic investigations of the Viviparidae (Gastropoda: Caenogastropoda) in the lakes of the Rift Valley area of Africa. Molecular Phylogenetics and Evolution. 52: 797-805. https://doi. org/10.1016/j.ympev.2009.05.007

STAMATAKIS A. 2014. RAxML version 8: a tool for phylogenetic analysis and post-analysis of large phylogenies. Bioinformatics 30: 1312-1313. https://doi. org/10.1093/bioinformatics/btu033

SZAROWSKA M., OSIKOWSKI A., HOFMAN S., FALNIOWSKI A. 2016. Pseudamnicola Paulucci, 1878 (Caenogastropoda: Truncatelloidea) from the Aegean Islands: a long or short story? Organisms Diversity \& Evolution 16: 121139. https://doi.org/10.1007/s13127-015-0235-5

Tamura K., Peterson D., Peterson N., Stecher G., NeI M., KumAR S. 2013. MEGA5: Molecular evolutionary genetics analysis using maximum likelihood, evolutionary distance, and maximum parsimony method. Molecular Biology and Evolution 28: 2731-2739. https://doi.org/10.1093/molbev/msr121

VAN BOCXLAER B., STRONG E. E., RICHTER R., STELBRINK B., RINTELEN T. VON 2018. Anatomical and genetic data reveal that Rivularia Heude, 1890 belongs to Viviparinae (Gastropoda: Viviparidae). Zoological Journal of the Linnean Society 182: 1-23. https://doi.org/10.1093/ zoolinnean/zlx014

WANG J. G., ZHANG D., JAKOVLIC I., WANG W. M. 2017. Sequencing of the complete mitochondrial genomes of eight freshwater snail species exposes pervasive paraphyly within the Viviparidae family (Caenogastropoda). PLoS ONE 12: E0181699. https://doi.org/10.1371/ journal.pone.0181699

WELTER-SCHULTES F. W. 2012. European non-marine molluscs, a guide for species identification. Planet Poster Editions, Göttingen. 
XIA X. 2000. Data analysis in molecular biology and evolution. Kluwer Academic Publishers, Boston, Dordrecht \& London.

XIA X. 2013. DAMBE: A comprehensive software package for data analysis in molecular biology and evolution. Molecular Biology and Evolution 30: 1720-1728. https://doi.org/10.1093/molbev/mst064
Xia X., Xie Z., Salemi M., Chen L., Wang Y. 2003. An index of substitution saturation and its application. Molecular Phylogenetics and Evolution 26: 1-7. https:// doi.org/10.1016/S1055-7903(02)00326-3

Received: December 4th, 2018

Revised: January 16th, 2019

Accepted: February 14th, 2019

Published on-line: March 19th, 2019 